DOI $10.31489 / 2020 \mathrm{M} 3 / 26-37$

MSC 34B37, 37C25, 37C75

\author{
M.J. Mardanov ${ }^{1}$, Y.A. Sharifov ${ }^{1,2}$, K.E. Ismayilova ${ }^{3}$ \\ ${ }^{1}$ Institute of Mathematics and Mechanics, ANAS, Baku, Azerbaijan \\ ${ }^{2}$ Baku State University, Baku, Azerbaijan \\ ${ }^{3}$ Baku Engineering University, Khirdalan City, Azerbaijan \\ (E-mail: misirmardanov@yahoo.com, sharifov22@rambler.ru,keismayilova@beu.edu.az)
}

\title{
Existence and uniqueness of solutions for the system of integro-differential equations with three-point and nonlinear integral boundary conditions
}

\begin{abstract}
The paper examines a system of nonlinear integro-differential equations with three-point and nonlinear integral boundary conditions. The original problem demonstrated to be equivalent to integral equations by using Green function. Theorems on the existence and uniqueness of a solution to the boundary value problems for the first order nonlinear system of integro- differential equations with three-point and nonlinear integral boundary conditions are proved. A proof of uniqueness theorem of the solution is obtained by Banach fixed point principle, and the existence theorem then follows from Schaefer's theorem.
\end{abstract}

Keywords: three-point boundary conditions, nonlinear integral boundary value problems, existence and uniqueness of solutions, fixed point theorems.

\section{Introduction}

Multipoint boundary value problems for ordinary differential equations play a crucial role in various applications. It is epitomized the fact that, given a dynamical system with $n$ degrees of freedom, there may exist exactly $n$ states detected at $n$ different times. A mathematical description of such a system results in an $n$-point boundary value problem. Another source of multipoint problems is the discretization of certain boundary value problems for partial differential equations over irregular domains with the method of lines. Multipoint problems for ordinary differential equations are a particular class of interface problems, and hence solvable with different techniques [1-4].

Integro-differential equations are encountered in many engineering and scientific disciplines, the problems can be represented as continuum phenomena and can be described approximately to partial differential equations. Many forms of these equations are possible. Some of the applications are unsteady aerodynamics and aeroelastic phenomena, viscoelasticity, viscoelastic panel in supersonic gas flow, fluid dynamics, electrodynamics of complex medium, many models of population growth, polymer rheology, neural network modeling, sandwich system identification, materials with fading memory, mathematical modeling of the diffusion of discrete particles in a turbulent fluid, heat conduction in materials with memory, theory of lossless transmission lines, theory of population dynamics, compartmental systems, nuclear reactors, and mathematical modeling of a hereditary phenomenon. For details, see [5-7] and the references therein. Integral boundary conditions have various applications in applied fields such as blood flow problems, chemical engineering, thermos-elasticity, underground water flow, population dynamics, and so forth. For a detailed description of the integral boundary conditions, we refer the reader to a recent paper [8]. For more details of nonlocal and integral boundary conditions, see [9-16] and references therein.

In the last few decades, the study of differential equations with nonlocal boundary conditions has been an interesting subject of mathematics, that has recently received the most significant attention of researchers; the reader is referred to [17-27]. It has been proposed by several authors that existence results for boundary value problems may be useful in real world problems. (see e.g., [28-30] and the references therein) 


\section{Problem statement and preliminaries}

In this section, we set up problem statement and lemmas which are used throughout this paper. We denote by $C\left([0, T], R^{n}\right)$ the Banach space of all continuous functions from $[0, T]$ into $R^{n}$ with the norm $\|x\|=\max \{|x(t)|: t \in[0, T]\}$, where $|\cdot|$ is the norm in space $R^{n}$.

We consider the existence, uniqueness of the system of nonlinear differential equations of the type

$$
\dot{x}(t)=f(t, x(t),(\chi x)(t)), \quad t \in[0, T],
$$

subject to three-point and nonlinear integral boundary conditions

$$
A x(0)+B x\left(t_{1}\right)+C x(T)=\int_{0}^{T} q(x(t)) d t,
$$

where $A, B, C$ are constant square matrices of order $n$ such that $\operatorname{det} N \neq 0, N=A+B+C$; $f:[0, T] \times R^{n} \times R^{n} \rightarrow R^{n} q: R^{n} \rightarrow R^{n}, g:[0, T] \times[0, T] \times R^{n} \rightarrow R^{n}$ are given functions, $t_{1}$ satisfies the condition $0<t_{1}<T$ and $(\chi x)(t)=\int_{0}^{t} g(t, s, x(s)) d s$.

For simplicity, the problem can be interpreted as solving the following problem:

Lemma 1. Suppose $\mu \in C\left([0, T], R^{n}\right)$ and $\operatorname{det} N \neq 0$. Then the unique solution of the following problem

$$
\dot{x}(t)=\mu(t), \quad t \in[0, T]
$$

with three-point boundary conditions

$$
A x(0)+B x\left(t_{1}\right)+C x(T)=\int_{0}^{T} \eta(s) d s,
$$

is given by

$$
x(t)=d+\int_{0}^{T} G(t, \tau) \mu(\tau) d \tau
$$

where

$$
G(t, \tau)= \begin{cases}G_{1}(t, \tau), & t \in\left[0, t_{1}\right] \\ G_{2}(t, \tau), & t \in\left(t_{1}, T\right]\end{cases}
$$

such that

$$
G_{1}(t, \tau)=\left\{\begin{array}{lr}
N^{-1} A, & 0 \leq \tau \leq t \\
-N^{-1}(B+C), & t<\tau \leq t_{1}, \\
-N^{-1} C, & t_{1}<\tau \leq T
\end{array}\right.
$$

and

$$
\begin{gathered}
G_{2}(t, \tau)=\left\{\begin{array}{lr}
N^{-1} A, & 0 \leq \tau \leq t_{1}, \\
N^{-1}(A+B), & t_{1}<\tau \leq t, \\
-N^{-1} C, & t<\tau \leq T,
\end{array}\right. \\
d=N^{-1} \int_{0}^{T} \eta(s) d s .
\end{gathered}
$$

Proof. If function $x=x(\cdot)$ is a solution of the differential equation (1), then for $t \in(0, T)$,

$$
x(t)=x_{0}+\int_{0}^{t} \mu(\tau) d \tau
$$


where $x_{0}$ is an arbitrary constant vector. Now we define $x_{0}$ so that, the function in equality (6) satisfies the condition (4)

$$
x_{0}=d-N^{-1} B \int_{0}^{t_{1}} \mu(t) d t-N^{-1} C \int_{0}^{T} \mu(t) d t .
$$

Now we put the value $x_{0}$ determined from the equality (7) in (6) and obtain

$$
x(t)=d-N^{-1} B \int_{0}^{t_{1}} \mu(t) d t-N^{-1} C \int_{0}^{T} \mu(t) d t+\int_{0}^{t} \mu(\tau) d \tau .
$$

Assume that, $t \in\left[0, t_{1}\right]$. Then we can write the equality (8) as follows:

$$
\begin{gathered}
x(t)=d-N^{-1} B\left(\int_{0}^{t} \mu(\tau) d \tau+\int_{t}^{t_{1}} \mu(\tau) d \tau\right)-N^{-1} C\left(\int_{0}^{t} \mu(\tau) d \tau+\int_{t}^{t_{1}} \mu(\tau) d \tau\right) \\
-N^{-1} C \int_{t_{1}}^{T} \mu(t) d t+\int_{0}^{t} \mu(\tau) d \tau .
\end{gathered}
$$

We get (9) combining similar terms, and using the common technique for simplifying:

$$
\begin{gathered}
x(t)=d+\left(E-N^{-1} B-N^{-1} C\right) \int_{0}^{t} \mu(\tau) d \tau-\left(N^{-1} B+N^{-1} C\right) \int_{t}^{t_{1}} \mu(\tau) d \tau \\
-N^{-1} C \int_{t_{1}}^{T} \mu(t) d t=d+N^{-1} A \int_{0}^{t} \mu(\tau) d \tau \\
-N^{-1}(B+C) \int_{t}^{t_{1}} \mu(\tau) d \tau-N^{-1} C \int_{t_{1}}^{T} \mu(t) d t
\end{gathered}
$$

where $E$ is an identity matrix.

Define new function as follows:

$$
G_{1}(t, \tau)=\left\{\begin{array}{lr}
N^{-1} A, & 0 \leq \tau \leq t \\
-N^{-1}(B+C), & t<\tau \leq t_{1} \\
-N^{-1} C, & t_{1}<\tau \leq T
\end{array}\right.
$$

Equality (10) can be rewritten as integral equation below:

$$
x(t)=d+\int_{0}^{T} G_{1}(t, \tau) \mu(\tau) d \tau .
$$

Now assume that, $t \in\left(t_{1}, T\right]$. Then we can write the equality (8) as follows:

$$
x(t)=d-N^{-1} B \int_{0}^{t_{1}} \mu(t) d t-N^{-1} C \int_{0}^{t_{1}} \mu(t) d t-N^{-1} C\left(\int_{t_{1}}^{t} \mu(\tau) d \tau+\int_{t}^{T} \mu(\tau) d \tau\right)
$$




$$
\begin{aligned}
& +\int_{0}^{t_{1}} \mu(t) d t+\int_{t_{1}}^{t} \mu(\tau) d \tau=d+\left(E-N^{-1} B-N^{-1} C\right) \int_{0}^{t_{1}} \mu(t) d t+\left(E-N^{-1} C\right) \int_{t_{1}}^{t} \mu(\tau) d \tau \\
& -N^{-1} C \int_{t}^{T} \mu(\tau) d \tau=d+N^{-1} A \int_{0}^{t_{1}} \mu(t) d t+N^{-1}(A+B) \int_{t_{1}}^{t} \mu(\tau) d \tau-N^{-1} C \int_{t}^{T} \mu(\tau) d \tau .
\end{aligned}
$$

We establish a new function as follows:

$$
G_{2}(t, \tau)=\left\{\begin{array}{lr}
N^{-1} A, & 0 \leq \tau \leq t_{1} \\
N^{-1}(A+B), & t_{1}<\tau \leq t \\
-N^{-1} C, & t<\tau \leq T
\end{array}\right.
$$

Hence, if $t \in\left(t_{1}, T\right]$, then we can write the equality (8) as follows:

$$
x(t)=d+\int_{0}^{T} G_{2}(t, \tau) \mu(\tau) d \tau .
$$

Thus, the solution of the boundary value problem (3)-(4) can be shown as follows:

$$
x(t)=d+\int_{0}^{T} G(t, \tau) \mu(\tau) d \tau .
$$

We showed that the argument given above is valid (5). Proof is completed.

Lemma 2. Assume that $f:[0, T] \times R^{n} \times R^{n} \rightarrow R^{n}, q: R^{n} \rightarrow R^{n}$ are given functions. Then the function $x(t)$ is a solution of the boundary value problem (1)-(2) if and only if $x(t)$ is a solution of the integral equation

$$
x(t)=D+\int_{0}^{T} G(t, \tau) f(\tau, x(\tau),(\chi x)(\tau)) d \tau,
$$

where

$$
D=N^{-1} \int_{0}^{T} q(x(t)) d t .
$$

Proof. Let $x(t)$ be a solution of the boundary value problem (1)-(2).Proving statements similar to Lemmas 1 this lemma can be derived. By checking directly we identify the solution of integral equation (11) satisfies the boundary value problem (1)-(2). Lemma 2 is proved.

\section{Existence results}

Let $P$ be an operator such that, $P: C\left([0, T], R^{n}\right) \rightarrow C\left([0, T], R^{n}\right)$ as

$$
(P x)(t)=N^{-1} \int_{0}^{T} q(x(t)) d t+\int_{0}^{T} G(t, \tau) f(\tau, x(\tau),(\chi x)(\tau)) d \tau .
$$

It is evident that, the problem (1)-(2) is equivalent to the fixed point problem $x=P x$. Thus, the problem (1)-(2) has a solution if and only if the operator $P$ has a fixed point.

In Lemma 1, we use the most basic fixed point theorem named the contraction mapping principle and it uses the assumptions: 
H1) There exist constants $M_{1}, M_{2}$ such that

$$
\left|f\left(t, x_{1}, x_{2}\right)-f\left(t, y_{1}, y_{2}\right)\right| \leq M_{1}\left|x_{1}-y_{1}\right|+M_{2}\left|x_{2}-y_{2}\right|
$$

for each $t \in[0, T]$ and all $x_{1}, x_{2}, y_{1}, y_{2} \in R^{n}$.

H2) There exists a constant $M_{3}$ such that

$$
|g(t, s, x)-g(t, s, y)| \leq M_{3}|x-y|
$$

for each $t, s \in[0, T]$ and all $x, y \in R^{n}$.

H3) There exists a constant $M_{4}$ such that

$$
|q(x)-q(y)| \leq M_{4}|x-y|
$$

for all $x, y \in R^{n}$.

Theorem 1. Assume that, the assumptions H1)-H3) hold, and

$$
L=\left[S\left(M_{1} T+\frac{M_{2} M_{3} T^{2}}{2}\right)+M_{4} T\left\|N^{-1}\right\|\right]<1,
$$

then the boundary-value problem (1)-(2) has a unique solution on $[0, T]$, where

$$
S=\max _{[0, T] \times[0, T]}\|G(t, \tau)\| .
$$

Proof. Setting $\max _{[0, T]}|f(t, 0,0)|=M_{f}, \max _{[0, T]}|q(0)|=m_{q}$ and choosing $r \geq \frac{M_{f} T S+m_{q} T\left\|N^{-1}\right\|}{1-L}$ we show that $P B_{r} \subset B_{r}$ where

$$
B_{r}=\left\{x \in C\left([0, T] R^{n}\right):\|x\| \leq r\right\}
$$

For $x \in B_{r}$, we have

$$
\begin{gathered}
\|(P x)(t)\| \leq\left\|N^{-1} \int_{0}^{T}(|q(x(t))-q(0)|+|q(0)|) d t\right\| \\
+\int_{0}^{T}|G(t, \tau)|(|f(\tau, x(\tau),(\chi x)(\tau))-f(\tau, 0,0)|+|f(\tau, 0,0)|) d \tau \\
\leq M_{4} T\left\|N^{-1}\right\|\|x\|+m_{q} T\left\|N^{-1}\right\|+S\left(M_{1} T+\frac{M_{2} M_{3} T^{2}}{2}\right)\|x\|+S T M_{f} \\
\leq\left[M_{4} T\left\|N^{-1}\right\|+S\left(M_{1} T+\frac{M_{2} M_{3} T^{2}}{2}\right)\right] r+S T M_{f}+m_{q} T\left\|N^{-1}\right\| \leq r .
\end{gathered}
$$

Now for any $x, y \in B_{r}$ we have

$$
\begin{aligned}
& |(P x)(t)-(P y)(t)| \leq \int_{0}^{T} \mid G(t, \tau)\left(f\left(\tau, x(\tau), \int_{0}^{t} g(t, s, x(s)) d s\right)-f\left(\tau, y(\tau), \int_{0}^{t} g(t, s, y(s)) d s\right) \mid d \tau\right. \\
& +\left|N^{-1} \int_{0}^{T}(q(x(t))-q(y(t))) d t\right| \\
& \leq S \int_{0}^{T}\left\{M_{1}|x(t)-y(t)|+M_{2}\left|\int_{0}^{t} g(t, s, x(s)) d s-\int_{0}^{t} g(t, s, y(s)) d s\right|\right\} d t \\
& +M_{4}\left\|N^{-1}\right\| \int_{0}^{T}|x(t)-y(t)| d t \leq\left[S\left(M_{1} T+\frac{M_{2} M_{3} T^{2}}{2}\right)+M_{4} T\left\|N^{-1}\right\|\right]\|x-y\|,
\end{aligned}
$$


or

$$
\|P x-P y\| \leq L\|x-y\| .
$$

It is seen that, $P$ is contraction by condition (12). So, the boundary-value problem (1)-(2) has a unique solution.

Theorem 2 (Schafer's fixed point theorem). Let $X$ be a Banach space. Assume that, $G: X \rightarrow X$ is a completely continuous operator and the set $\rho=\{x \in X \mid x=\beta G x, 0<\beta<1\}$ is bounded. Then $G$ has a fixed point in $X$.

Now we apply Schafer's fixed point theorem and it uses the following assumption:

Theorem 3. Assume that the functions $f:[0, T] \times R^{n} \times R^{n} \rightarrow R^{n}$ and $q: R^{n} \rightarrow R^{n}$ are continuous and there exist functions $\rho, \lambda \in C\left([0, T], R^{+}\right)$such that $|f(t, x(t),(\chi x)(t))| \leq \rho(t),|q(x(t))| \leq \lambda(t)$, $\forall t \in[0, T], x \in C\left([0, T], R^{n}\right)$ and with $\sup _{t \in[0, T]}|\rho(t)|=\|\rho\|, \sup _{t \in[0, T]}|\lambda(t)|=\|\lambda\|$. Then the boundary value problem (1)-(2) has at least one solution on $[0, T]$.

Proof. Let $P$ be the operator defined in (12). We use Schaefer's fixed point theorem to prove that $P$ has a fixed point. The proof will be given in several steps.

Step 1: Here we prove that $P$ is continuous. Let $\left\{x_{n}\right\}$ be a sequence such that $x_{n} \rightarrow x$ in $C\left([0, T] ; R^{n}\right)$. Then, for each $t \in[0, T]$

$$
\begin{aligned}
& \left|(P x)(t)-\left(P x_{n}\right)(t)\right| \\
& =\left|N^{-1} \int_{0}^{T}\left(q(x(t))-q\left(x_{n}(t)\right)\right) d t+\int_{0}^{T} G(t, \tau)\left(f(\tau, x(\tau),(\chi x)(\tau))-f\left(\tau, x_{n}(\tau),\left(\chi x_{n}\right)(\tau)\right)\right) d \tau\right| \\
& \quad \leq\left[S\left(M_{1} T+\frac{M_{2} M_{3} T^{2}}{2}\right)+M_{4} T\left\|N^{-1}\right\|\right]\left|x(t)-x_{n}(t)\right| \leq L\left\|x-x_{n}\right\| .
\end{aligned}
$$

From here we get $\left\|(P x)(t)-\left(P x_{n}\right)(t)\right\| \rightarrow 0$ as $n \rightarrow \infty$, which implies that the operator $P$ is continuous.

Step 2: $P$ maps bounded sets into bounded sets in $C\left([0, T] ; R^{n}\right)$. Indeed, it is enough to show that for any $\eta>0$ there exists a positive constant $\omega$ such that for each $x \in B_{\eta}=\left\{x \in C\left([0, T] ; R^{n}\right):\|x\| \leq \eta\right\}$ we have $\|P(x)\| \leq \omega$. We have for each $t \in[0, T]$

$$
|(P x)(t)| \leq T\left\|N^{-1}\right\|\|\lambda\|+T S\|\rho\| .
$$

This implies that

$$
\|(P x)(t)\| \leq T\left\|N^{-1}\right\|\|\lambda\|+T S\|\rho\| .
$$

Step 3.The operator $P$ maps bounded sets into equicontinuous sets of $C\left([0, T], R^{n}\right)$. Let $\tau_{1}, \tau_{2} \in[0, T], \tau_{1}<\tau_{2}, B_{\eta}$ be a bounded set of $C\left([0, T] ; R^{n}\right)$ as in Step 2, and let $x \in B_{\eta}$. Case 1 . Let be $\tau_{1}, \tau_{2} \in\left[0, t_{1}\right]$. Then,

$$
\begin{gathered}
(P x)\left(\tau_{2}\right)-(P x)\left(\tau_{1}\right)=N^{-1} A \int_{0}^{\tau_{2}} f(\tau, x(\tau),(\chi x)(\tau)) d \tau \\
-N^{-1}(B+C) \int_{\tau_{2}}^{t_{1}} f(\tau, x(\tau),(\chi x)(\tau)) d \tau-N^{-1} A \int_{0}^{\tau_{1}} f(\tau, x(\tau),(\chi x)(\tau)) d \tau \\
+N^{-1}(B+C) \int_{\tau_{1}}^{t_{1}} f(\tau, x(\tau),(\chi x)(\tau)) d \tau=\int_{\tau_{1}}^{\tau_{2}} f(\tau, x(\tau),(\chi x)(\tau)) d \tau .
\end{gathered}
$$


Case 2: Let be $\tau_{1} \in\left[0, t_{1}\right]$ and $\tau_{2} \in\left(t_{1}, T\right]$. Then

$$
\begin{gathered}
(P x)\left(\tau_{2}\right)-(P x)\left(\tau_{1}\right)=N^{-1} A \int_{0}^{t_{1}} f(\tau, x(\tau),(\chi x)(\tau)) d \tau \\
+N^{-1}(A+B) \int_{t_{1}}^{\tau_{2}} f(\tau, x(\tau),(\chi x)(\tau)) d \tau-N^{-1} C \int_{\tau_{2}}^{T} f(\tau, x(\tau),(\chi x)(\tau)) d \tau \\
-N^{-1} A \int_{\tau_{1}}^{t_{1}} f(\tau, x(\tau),(\chi x)(\tau)) d \tau+N^{-1}(B+C) \int_{\tau_{1}}^{t_{1}} f(\tau, x(\tau),(\chi x)(\tau)) d \tau \\
+N^{-1} C \int_{t_{1}}^{T} f(\tau, x(\tau),(\chi x)(\tau)) d \tau=\int_{\tau_{1}}^{\tau_{2}} f(\tau, x(\tau),(\chi x)(\tau)) d \tau .
\end{gathered}
$$

Apparently, in both cases

$$
\left|(P x)\left(\tau_{2}\right)-(P x)\left(\tau_{1}\right)\right| \leq \int_{\tau_{1}}^{\tau_{2}}|f(\tau, x(\tau),(\chi x)(\tau))| d \tau .
$$

As $\tau_{2} \rightarrow \tau_{1}$, the right hand side of the preceding inequality tends to zero. Taking into account that the mapping $P$ is continuous and equivalently continuous, we conclude that the mapping $P: C\left([0, T], R^{n}\right) \rightarrow C\left([0, T], R^{n}\right)$ is completely continuous by Arzela-Ascoli theorem.

Step 4. We show that a set $\Omega=\left\{x \in C\left([0, T], R^{n}\right): x=\lambda P(x)\right.$, for some $\left.0<\lambda<1\right\}$ is bounded. Assume that, $x=\lambda P(x)$ for some $0<\lambda<1$. Then for each $t \in[0, T]$, we can write

$$
x(t)=\lambda N^{-1} \int_{0}^{T} q(x(t)) d t+\lambda \int_{0}^{T} G(t, \tau) f(\tau, x(\tau),(\chi x)(\tau)) d \tau .
$$

From here we get

$$
\|x\| \leq T\left\|N^{-1}\right\|\|\lambda\|+T S\|\rho\| .
$$

Therefore, the set $\Omega$ is bounded. The conclusion of Theorem 2 applies and the operator $P$ has at least one fixed point. So, there exists at least one solution for the problem (1)-(2) on $[0, T]$.

\section{Example}

Consider the following system of integro-differential equation

$$
\left\{\begin{array}{l}
\dot{x}_{1}=\sin \alpha x_{2} \\
\dot{x}_{2}=\cos \left(\beta \int_{0}^{t} \frac{\sin \left(\gamma x_{1}\right)}{1+t^{2}} d t\right)
\end{array}\right.
$$

subject to

$$
\left\{\begin{array}{c}
x_{1}(0)+x_{2}(0)-x_{2}\left(\frac{1}{2}\right)=1 \\
-x_{1}\left(\frac{1}{2}\right)+x_{1}(1)+x_{2}(1)=\int_{0}^{1} \cos \delta x_{2}(t) d t .
\end{array}\right.
$$


Evidently,

$$
\begin{gathered}
A=\left(\begin{array}{ll}
1 & 1 \\
0 & 0
\end{array}\right), \quad B=\left(\begin{array}{cc}
0 & -1 \\
-1 & 0
\end{array}\right), \quad C=\left(\begin{array}{ll}
0 & 0 \\
1 & 1
\end{array}\right), \\
A+B+C=\left(\begin{array}{ll}
1 & 0 \\
0 & 1
\end{array}\right) .
\end{gathered}
$$

For $t \in\left[0, \frac{1}{2}\right]$, we obtain

and for $t \in\left(\frac{1}{2}, 1\right]$

$$
G_{1}(t, \tau)= \begin{cases}\left(\begin{array}{cc}
1 & 1 \\
0 & 0
\end{array}\right), & 0 \leq \tau \leq t \\
\left(\begin{array}{cc}
0 & 1 \\
0 & -1
\end{array}\right), & t<\tau \leq \frac{1}{2} \\
\left(\begin{array}{cc}
0 & 0 \\
-1 & -1
\end{array}\right), & \frac{1}{2}<\tau \leq 1\end{cases}
$$

$$
G_{2}(t, \tau)=\left\{\begin{array}{cc}
\left(\begin{array}{cc}
1 & 1 \\
0 & 0
\end{array}\right), & 0 \leq \tau \leq \frac{1}{2} \\
\left(\begin{array}{cc}
1 & 0 \\
-1 & 0
\end{array}\right), & \frac{1}{2}<\tau \leq t \\
\left(\begin{array}{cc}
0 & 0 \\
-1 & -1
\end{array}\right), & t<\tau \leq 1 .
\end{array}\right.
$$

Obviously, $M_{1}=|\alpha|, M_{2}=|\beta|, M_{3}=|\gamma|, M_{4}=|\delta|$ and $\|S\| \leq 2$. If $L=2\left(|\alpha|+\frac{|\beta||\gamma|}{2}\right)+|\delta|<1$, then boundary value problem (A)-(B) has a unique solution.

\section{References}

1 Cannon J.R. The solution of the heat equation subject to the specification of energy / J.R. Cannon // Quart. Appl. Math. - 1963, No. 21. - P. 155-160.

2 Cannon J.R. The One-dimensional Heat Equation / J.R. Cannon // Encyclopedia of Mathematics and its Applications, Vol. 23, Addison-Wesley Publishing Company, advanced Book Program, Reading, MA, 1984.

3 Timoshenko S. Theory of elastic stability / S. Timoshenko. - McGraw-Hill, New-York, 1961.

4 Urabe M. An existence theorem for multi-point boundary value problems / M. Urabe // Funkcialaj Ekvacioj. - 1966. - No. 9. - P. 43-60.

5 Ahmad B. On the existence of $T$-periodic solutions for Duffing type integro-differential equations with p-Laplacian / B. Ahmad // Lobachevskii Journal of Mathematics - 2008. - 29. - No. 1. - P. 1-4.

6 Luo Z. New results for the periodic boundary value problem for impulsive integro-differential equations / Z. Luo, J.J Nieto // Nonlinear Analysis: Theory, Methods \& Applications - 2009. - 70. - No. 6. - P. 2248-2260.

7 Mesloub S. On a mixed nonlinear one point boundary value problem for an integro-differential equation / S. Mesloub // Boundary Value Problems - 2008. Article ID 814947. 1-8.

8 Ahmad B. Analytic approximation of solutions of the forced Duffing equation with integral boundary conditions / B. Ahmad, A. Alsaedi, B.S. Alghamdi // Nonlinear Analysis: Real World Applications. - 2008. - 9, - No. 4. - P. 1727-1740.

9 Ahmad B. Existence of approximate solutions of the forced Duffing equation with discontinuous type integral boundary conditions / B. Ahmad, A. Alsaedi // Nonlinear Analysis: Real World Applications. - 2009. - 10. - No. 1. - P. 358-367. 
10 Boucherif A. Second-order boundary value problems with integral boundary conditions / A. Boucherif // Nonlinear Analysis: Theory, Methods \& Applications. - 2009. - 70. - No. 1. P. 364-371.

11 Yang Z. Existence of nontrivial solutions for a nonlinear Sturm-Liouville problem with integral boundary conditions / Z. Yang // Nonlinear Analysis: Theory, Methods \& Applications - 2008. - 68. - No. 1. - P. 216-225.

12 Mardanov M.J. Existence and uniqueness of solutions for first-order nonlinear differential equations with two-point and integral boundary conditions / M.J. Mardanov, Y.A. Sharifov, H.H. Molaei // Electronic Journal of Differential Equations. - 2014. - 259. - P. 1-8.

13 Mardanov M.J. Existence and Uniqueness of Solutions for the System of First-order Nonlinear Differential Equations with Three-point and Integral Boundary Conditions / M.J. Mardanov, Y.A. Sharifov, K.E. Ismayilova, S.A. Zamanova // European Journal of Pure and Applied Mathematics. - 2019. - 12. - No. 3. - P. 756-770.

14 Mardanov M.J. Existence results for first order nonlinear impulsive differential equations with nonlocal boundary conditions / M.J. Mardanov, Y.A. Sharifov // AIP Conference Proceedings. - 2015. - 1676(1), No. 020015.

15 Mardanov M.J. Existence and uniqueness of solutions for nonlinear impulsive differential equations with nonlocal boundary conditions / M.J. Mardanov, Y.A. Sharifov, F.M. Zeynally // Vestn. Tomsk. Gos. Univ. Mat. Mekh. - 2019. - No. 60. - P. 61-72.

16 Mardanov M.J. Existence and uniqueness of the solutions to impulsive nonlinear integrodifferential equations with nonlocal boundary conditions / M.J. Mardanov, Y.A. Sharifov, F.M. Zeynally // Proceedings of the Institute of Mathematics and Mechanics, National Academy of Sciences of Azerbaijan. - 2019. - 45. - No. 2. - P. 222-233.

17 Abdullayev V.M. Numerical solution to optimal control problems with multipoint and integral conditions / V.M. Abdullayev // Proceedings of the Institute of Mathematics and Mechanics, National Academy of Sciences of Azerbaijan. - 2018. - 44. - No. 2. - P. 171-186.

18 Ahmad B. Generalized quasilinearization method for a first order differential equation with integral boundary condition / B. Ahmad, S. Sivasundaram, R.A. Khan // Dyn. Contin. Discrete Impuls. Syst., Ser. A Math. Anal. - 2005. - 12. - No. 2 - P. 289-296.

19 Aida-zade K.R. An approach for solving nonlinearly loaded problems for linear ordinary differential equations / K.R. Aida-zade // Proceedings of the Institute of Mathematics and Mechanics, National Academy of Sciences of Azerbaijan. - 2018. - 44. - No. 2. - P. 338-350.

20 Ashyralyev A. Optimal control problem for impulsive systems with integral boundary conditions / A. Ashyralyev, Y.A. Sharifov // AIP Conference Proceedings. - 2012. - 1470(1). - P. 12-15.

21 Ashyralyev A. Existence and uniqueness of solutions for nonlinear impulsive differential equations with two-point and integral boundary conditions / A. Ashyralyev, Y.A. Sharifov // AIP Conference Proceedings. - 2012. - 1470(1). - P. 8-11.

22 Ashyralyev A. Existence and uniqueness of solutions for nonlinear impulsive differential equations with two-point and integral boundary conditions / A. Ashyralyev, Y.A. Sharifov // Advances in Difference Equations. - 2013. - 173. - P. 1-11.

23 Ashyralyev A. Optimal control problems for impulsive systems with integral boundary conditions / A. Ashyralyev, Y.A. Sharifov // Electron. Journal Differential Equations. - 2013. - 80. - P. 1-11.

24 Mardanov M.J. Existence and uniqueness of solutions for nonlinear impulsive differential equations with three-point boundary conditions / M.J. Mardanov, Y.A. Sharifov, K.E. Ismayilova // eJournal of Analysis and Applied Mathematics. - 2018. - No. 1. - P. 21-36. 
25 Mardanov M.J. Existence and uniqueness of solutions for nonlinear impulsive differential equations with three-point and integral boundary conditions / M.J. Mardanov, Y.A. Sharifov, R.A. Sardarova, H.N. Aliyev // Azerbaijan Journal of Mathematics. - 2020. - 10. - No. 1. P. 110-126.

26 Murty K.N. Existence and uniqueness of solution to three-point boundary value problems associated with nonlinear first order systems of differential equations / K.N. Murty, S. Sivasundaram // J. Math. Anal. Appl. - 1993. - 173. - P. 158-164.

27 Mardanov M.J. Existence and uniqueness of solutions for the first-order non-linear differential equations with three-point boundary conditions/ M.J. Mardanov, Y.A. Sharifov, K.E. Ismayilova // Filomat - 2019. - 33(5). - P. 1387-1395.

28 Kozhanov A.I. On the solvability of boundary value problems with a nonlocal boundary condition of an integral form for the multidimensional hyperbolic equations / A.I. Kozhanov, L.S. Pulkina // Differential Equations - 2006. - 42. - P. 1233-1246.

29 Pulkina L.S. Nonlocal problems for hyperbolic equations with degenerate integral conditions / L.S. Pulkina // Electronic Journal of Differential Equations - 2016. - 193, - P. 1-12.

30 Khaldi R. (2019). Solvability of singular multi-point boundary value problems / R. Khaldi, A. Guezane-Lakoud, N. Hamidane // Proceedings of the Institute of Mathematics and Mechanics, National Academy of Sciences of Azerbaijan - 2019. - 45. - No.1. - P. 3-14.

М.Дж. Марданов, Я.А. Шарифов, К.Е. Исмайилова

\title{
Үш нүктелі және интегралдық шеттік шарттарымен
}

берілген сызықты емес интегралды-дифференциалдық теңдеулер жүйесінің шешімінің бар болуы және жалғыздығы

\begin{abstract}
Мақалада үш нүктелі және интегралдық шекаралық шарттарымен берілген сызықты емес интегралды-дифференциалдық теңдеулер жүйесі зерттелген. Бастапқыда, Грин функциясы арқылы эквивалентті интегралдық теңдеуге алып келді. Кейіннен, қозғалмайтын нүктелер туралы теореманы қолдана отырып, шеттік есептің шешімінің бар болуы және жалғыздығының жеткілікті шарты алынды. Шешімінің жалғыздығы теоремасының дәлелдемесі қозғалмайтын нүкте туралы Банах принципі бойынша алынды, содан кейін бар болуы теоремасы Шефер теоремасынан шығады.
\end{abstract}

Kiлm сөздер: үш нүктелі шекаралық шарттар, сызықты емес интегралдық шеттік есептер, шешімінің бар болуы және жалғыздығы, қозғалмайтын нүкте туралы теорема.

\author{
М.Дж. Марданов, Я.А. Шарифов, К.Е. Исмайилова
}

\section{Существование и единственность решений для систем интегро-дифференциальных уравнений с трёхточечными и нелинейными интегральными краевыми условиями}

В статье исследована система нелинейных интегро-дифференциальных уравнений с трехточечными и интегральными граничными условиями. Сначала с помощью функции Грина она приведена к эквивалентному интегральному уравнению. Далее, с использованием теоремы о неподвижных точках, получены достаточные условия существования и единственности решения краевой задачи. Доказательство теоремы единственности решения получено по принципу Банаха о неподвижной точке, а затем теорема существования следует из теоремы Шефера.

Ключевые слова: трехточечные граничные условия, нелинейные интегральные краевые задачи, существование и единственность решений, теоремы о неподвижной точке. 


\section{References}

1 Cannon, J.R. (1963). The solution of the heat equation subject to the specification of energy. Quart. Appl. Math., 21(2), 155-160.

2 Cannon, J.R. (1984). The One-dimensional Heat Equation, vol. 23, Encyclopedia of Mathematics and its Applications / Addison-Wesley Publishing Company, Advanced Book Program, Reading, MA.

3 Timoshenko, S. (1961). Theory of elastic stability, McGraw-Hill, New-York.

4 Urabe, M. (1966). An existence theorem for multi-point boundary value problems. Funkcialaj Ekvacioj., 9, 43-60.

5 Ahmad, B. (2008). "On the existence of $T$-periodic solutions for Duffing type integro-differential equations with $p$-Laplacian. Lobachevskii Journal of Mathematics, 29(1), 1-4.

6 Luo, Z., \& Nieto, J.J. (2009). New results for the periodic boundary value problem for impulsive integro-differential equations. Nonlinear Analysis: Theory, Methods \& Applications, 70(6), 22482260 .

7 Mesloub, S. (2008). On a mixed nonlinear one point boundary value problem for an integrodifferential equation. Boundary Value Problems, Vol. 2008, Article ID 814947, 1-8.

8 Ahmad, B., Alsaedi, A., \& Alghamdi, B.S. (2008). Analytic approximation of solutions of the forced Duffing equation with integral boundary conditions. Nonlinear Analysis: Real World Applications, 9(4), 1727-1740.

9 Ahmad, B., \& Alsaedi, A.(2009) Existence of approximate solutions of the forced Duffing equation with discontinuous type integral boundary conditions. Nonlinear Analysis: Real World Applications, 10(1), 358-367.

10 Boucherif, A. (2009). Second-order boundary value problems with integral boundary conditions. Nonlinear Analysis: Theory, Methods \& Applications, 70(1), 364-371.

11 Yang, Z. (2008). Existence of nontrivial solutions for a nonlinear Sturm-Liouville problem with integral boundary conditions. Nonlinear Analysis: Theory, Methods \& Applications, 68(1), 216225.

12 Mardanov, M.J., Sharifov, Y.A., \& Molaei, H.H. (2014). Existence and uniqueness of solutions for first-order nonlinear differential equations with two-point and integral boundary conditions. Electronic Journal of Differential Equations, 2014(259), 1-8.

13 Mardanov, M.J., Sharifov, Y.A., Ismayilova, K.E., \& Zamanova, S.A. (2019). Existence and Uniqueness of Solutions for the System of First-order Nonlinear Differential Equations with Three-point and Integral Boundary Conditions. European Journal of Pure and Applied Mathematics, 12(3), 756-770.

14 Mardanov, M.J. \& Sharifov, Y.A. (2015). Existence results for first order nonlinear impulsive differential equations with nonlocal boundary conditions. AIP Conference Proceedings, 1676 (1), 020015 .

15 Mardanov, M.J., Sharifov, Y.A, \& Zeynally, F.M. (2019). Existence and uniqueness of solutions for nonlinear impulsive differential equations with nonlocal boundary conditions. Vestn. Tomsk. Gos. Univ. Mat. Mekh., 60, 61-72.

16 Mardanov, M.J., Sharifov, Y.A, \& Zeynally, F.M. (2019). Existence and uniqueness of the solutions to impulsive nonlinear integro-differential equations with nonlocal boundary conditions. Proceedings of the Institute of Mathematics and Mechanics, National Academy of Sciences of Azerbaijan, 45(2), 222-233. 
17 Abdullayev, V.M. (2018). Numerical solution to optimal control problems with multipoint and integral conditions. Proceedings of the Institute of Mathematics and Mechanics, National Academy of Sciences of Azerbaijan, 44(2), 171-186.

18 Ahmad, B., Sivasundaram, S., \& Khan, R.A. (2005). Generalized quasilinearization method for a first order differential equation with integral boundary condition. Dyn. Contin. Discrete Impuls. Syst., Ser. A Math. Anal., 12(2), 289-296.

19 Aida-zade, K.R. (2018). An approach for solving nonlinearly loaded problems for linear ordinary differential equations. Proceedings of the Institute of Mathematics and Mechanics, National Academy of Sciences of Azerbaijan, 44(2), 338-350.

20 Ashyralyev, A., \& Sharifov Y.A. (2012). Optimal control problem for impulsive systems with integral boundary conditions. AIP Conference Proceedings, 1470(1), 12-15.

21 Ashyralyev, A., \& Sharifov Y.A. (2012). Existence and uniqueness of solutions for nonlinear impulsive differential equations with two-point and integral boundary conditions. AIP Conference Proceedings, 1470(1), 8-11.

22 Ashyralyev, A., \& Sharifov Y.A. (2013). Existence and uniqueness of solutions for nonlinear impulsive differential equations with two-point and integral boundary conditions. Advances in Difference Equations, 2013(173), 1-11.

23 Ashyralyev, A., \& Sharifov Y.A. (2013). Optimal control problems for impulsive systems with integral boundary conditions, Electron. Journal Differential Equations, 2013(80), 1-11.

24 Mardanov, M.J., Sharifov, Y.A. \& Ismayilova, K.E. (2018). Existence and uniqueness of solutions for nonlinear impulsive differential equations with three-point boundary conditions. e-Journal of Analysis and Applied Mathematics 1, 21-36.

25 Mardanov, M.J., Sharifov, Y.A., Sardarova, R.A., \& Aliyev, H.N. (2020). Existence and uniqueness of solutions for nonlinear impulsive differential equations with three-point and integral boundary conditions. Azerbaijan Journal of Mathematics, 10(1), 110-126.

26 Murty K.N., \& Sivasundaram S. (1993). Existence and uniqueness of solution to three-point boundary value problems associated with nonlinear first order systems of differential equations. J. Math. Anal. Appl. 173, 158-164.

27 Mardanov, M.J., Sharifov, Y.A. \& Ismayilova, K.E. (2019). Existence and uniqueness of solutions for the first-order non-linear differential equations with three-point boundary conditions. Filomat, 33(5), 1387-1395.

28 Kozhanov, A.I. \& Pulkina, L.S. (2006). On the solvability of boundary value problems with a nonlocal boundary condition of an integral form for the multidimensional hyperbolic equations. Differential Equations, 42(9), 1233-1246.

29 Pulkina, L.S. (2016). Nonlocal problems for hyperbolic equations with degenerate integral conditions. Electronic Journal of Differential Equations, 2016(193), 1-12.

30 Khaldi, R., Guezane-Lakoud, A. \& Hamidane, N. (2019). Solvability of singular multi-point boundary value problems. Proceedings of the Institute of Mathematics and Mechanics, National Academy of Sciences of Azerbaijan, 45(1), 3-14. 